\title{
Increased therapeutic potential of an experimental anti-mitotic inhibitor SB 715992 by genistein in PC-3 human prostate cancer cell
} line

\author{
David A Davis ${ }^{1,2}$, Sarah H Sarkar ${ }^{1}$, Maha Hussain ${ }^{3}$, Yiwei Li $^{1}$ and \\ Fazlul H Sarkar*1
}

Address: ${ }^{1}$ Departments of Pathology, Karmanos Cancer Institute, Wayne State University School of Medicine, Detroit, MI, USA, ${ }^{2}$ Department of Natural Sciences, University of Michigan-Dearborn, Michigan, Ann Arbor, MI, USA and ${ }^{3}$ Division of Hematology/Oncology, Department of Internal Medicine, University of Michigan, Ann Arbor, MI, USA

Email: David A Davis - davisad@bu.edu; Sarah H Sarkar - sarkar@wayne.edu; Maha Hussain - mahahuss@med.umich.edu; Yiwei Li - yiweili@med.wayne.edu; Fazlul H Sarkar* - fsarkar@med.wayne.edu

* Corresponding author

Published: 24 January 2006

BMC Cancer 2006, 6:22 doi:10.1186/147|-2407-6-22
Received: 03 October 2005

Accepted: 24 January 2006

This article is available from: http://www.biomedcentral.com/I47I-2407/6/22

(C) 2006 Davis et al; licensee BioMed Central Ltd.

This is an Open Access article distributed under the terms of the Creative Commons Attribution License (http://creativecommons.org/licenses/by/2.0), which permits unrestricted use, distribution, and reproduction in any medium, provided the original work is properly cited.

\begin{abstract}
Background: Kinesin spindle proteins (KSP) are motor proteins that play an essential role in mitotic spindle formation. $\mathrm{HsEg} 5$, a KSP, is responsible for the formation of the bipolar spindle, which is critical for proper cell division during mitosis. The function of $\mathrm{HsEg} 5$ provides a novel target for the manipulation of the cell cycle and the induction of apoptosis. SB715992, an experimental KSP inhibitor, has been shown to perturb bipolar spindle formation, thus making it an excellent candidate for anti-cancer agent. Our major objective was a) to investigate the cell growth inhibitory effects of SB7I5992 on PC-3 human prostate cancer cell line, b) to investigate whether the growth inhibitory effects of SB7/5992 could be enhanced when combined with genistein, a naturally occurring isoflavone and, $\mathrm{c}$ ) to determine gene expression profile to establish molecular mechanism of action of SB7I5992.
\end{abstract}

Methods: PC-3 cells were treated with varying concentration of SB715992, $30 \mu \mathrm{M}$ of genistein, and SB7I5992 plus $30 \mu \mathrm{M}$ of genistein. After treatments, PC-3 cells were assayed for cell proliferation, induction of apoptosis, and alteration in gene and protein expression using cell inhibition assay, apoptosis assay, microarray analysis, real-time RT-PCR, and Western Blot analysis.

Results: SB7 5992 inhibited cell proliferation and induced apoptosis in PC-3 cells. SB7 I5992 was found to regulate the expression of genes related to the control of cell proliferation, cell cycle, cell signaling pathways, and apoptosis. In addition, our results showed that combination treatment with SB7I5992 and genistein caused significantly greater cell growth inhibition and induction of apoptosis compared to the effects of either agent alone.

Conclusion: Our results clearly show that SB7I5992 is a potent anti-tumor agent whose therapeutic effects could be enhanced by genistein. Hence, we believe that SB7I5992 could be a novel agent for the treatment of prostate cancer with greater success when combined with a nontoxic natural agent like genistein. 


\section{Background}

Prostate cancer is one of the leading causes of cancer fatality in the United States amongst males [1]. Development of chemotherapeutic agents to induce apoptosis of tumor cells with lower toxicity in patients is currently being investigated by many scientists. Many of these agents have been synthetically engineered or derived from natural plant products. Genistein, a predominant soy isoflavone, has been shown to inhibit proliferation in tumor cells in vitro and in vivo without any visible toxicity to normal cells $[2,3]$. In addition, individuals with diets high in soy show considerably lower incidences of prostate cancer [4]. At the molecular level, genistein is known as a protein tyrosine kinase inhibitor and has been shown to alter the expression of genes, which are critical for the control of cell proliferation, apoptosis, and cell signalling [5]. Tyrosine kinase is involved in many multi-cellular aspects of an organism [6]. In prostate epithelial cells, tyrosine kinase regulates cell-to-cell signaling that regulates growth, differentiation, adhesion, motility and programmed cell death, which ultimately play significant roles in the manifestation of human disease states such as diabetes and cancer [6]. With this information at hand, we studied the growth inhibitory effects of genistein with a new experimental anti-mitotic agent SB715992, chemically defined as $n$-(3amino-propyl)-n- [R-1-(3-benzyl-7-chloro-4-oxo-3, 4-dihydroquinazolin-2-yl)-2-methyl-propyl]-4-methyl-benzanide methanesulfonate $\left(\mathrm{C}_{30} \mathrm{H}_{33} \mathrm{ClN}_{4} \mathrm{O}_{2} \mathrm{CH}_{4} \mathrm{O}_{3} \mathrm{~S}\right)$.

SB715992 is a kinesin spindle protein (KSP) inhibitor whose cellular effects may provide a novel treatment for cancer. Human KSP, encoded by HsEg5, has been shown to localize along interpolar spindle microtubules and at the spindle poles. KSP plays a rigid role in cell mitosis and is required for cell cycle progression. It mediates centrosome separation and formation of the bipolar mitotic spindle, which is important for cell mitosis. Inactivation of KSP caused improper cell division and cell cycle arrest during mitosis, ultimately leading to apoptotic cell death [7]. In this study, we investigated the cellular and molecular effects of SB715992 treatment alone and in combination with genistein on PC-3 human prostate cancer cells in vitro.

\section{Methods \\ Cell culture and reagents}

PC-3 human prostate cancer cells (ATCC, Manassas, VA, USA) were cultured in RPMI 1640 medium (Invitrogen, Carlsbad, CA, USA) with $10 \%$ fetal bovine serum in a $5 \%$ $\mathrm{CO}_{2}$ atmosphere at $37^{\circ} \mathrm{C}$. Kinesin spindle protein inhibitor, SB715992, (GSK, GlaxoSmithKline, UK) was dissolved in distilled water to prepare a $1 \mu \mathrm{M}$ stock solution. SB715992 was then applied directly to RPMI 1640 medium in experimental cultures at varying concentration. Tyrosine kinase inhibitor, genistein (Toronto
Research Chemicals, North York, Ontario, Canada), was dissolved in sterile $0.1 \mathrm{M} \mathrm{Na}_{2} \mathrm{CO}_{3}$ to prepare a $10 \mathrm{mM}$ stock solution. Subsequently, genistein was also applied directly to RPMI 1640 medium at the concentration of 30 $\mu \mathrm{M}$ in experimental cultures.

\section{Cell inhibition assay}

PC-3 prostate cancer cells were seeded in 96 well plates at a density of $4 \times 10^{3}$ cells/well. PC-3 cells were incubated for 24 hours to allow attachment to the surface of each well of the tissue culture plate. Then, the cells were treated with varying concentration of reagents and incubated for 1 to 3 days. First, PC-3 cells were treated with 15 and 30 nM of SB7159992, respectively. Second, PC-3 cells were subjected to combinational treatments with 7.5 or $10 \mathrm{nM}$ of SB715992 plus $30 \mu \mathrm{M}$ of genistein. Finally, PC-3 cells were pre-treated with $30 \mu \mathrm{M}$ of genistein for 24 hours followed by treatment with $15 \mathrm{nM}$ of SB715992. Control cells were treated with $0.3 \mathrm{mM} \mathrm{Na}_{2} \mathrm{CO}_{3}$ (vehicle control). After treatment, PC3 cells were incubated at $37^{\circ} \mathrm{C}$ with MTT (0.5 mg/ml, Sigma, St. Louis, MO, USA) for 2 hours and isopropyl alcohol at room temperature for 1 hour. The spectrophotometric absorbance of each sample was then determined by using ULTRA Multifunctional Micro Plate Reader (TECAN, Durham, NC, USA) at $595 \mathrm{~nm}$.

\section{Histone/DNA ELISA for detecting apoptosis}

Apoptotic cell death was quantified with the use of Cell Apoptosis ELISA Detection Kit (Roache, Palo Alto, CA, USA). PC-3 cells were seeded in 6 well plates at a density of $5.0 \times 10^{4} /$ well and allowed 24 hours to adhere to the surface of each well. Then, the cells were treated with varying concentrations of reagents as described above. After treatment, cytoplasmic histone/DNA fragments from PC3 cells were extracted and adhered to an immobilized anti-histone antibody plate. Thereafter, a peroxidase-conjugated anti-DNA antibody was used for detection of adhered histone/DNA fragments. A substrate for peroxidase was then added to each well containing each experimental condition. The spectrophotometric absorbance of each sample was then determined by using ULTRA Multifunctional Micro Plate Reader (TECAN, Durham, NC, USA) at $405 \mathrm{~nm}$.

\section{DNA ladder analysis for detecting apoptosis}

PC-3 cells were seeded in $100 \mathrm{~mm}$ dishes at $3.5 \times 10^{5}$ cells/ dish and allowed to adhere and grow for 36 hours. Following growth and attachment, PC-3 cells were treated with 15 nM of SB715992 for 48 and 72 hours. After treatment, cellular cytoplasmic DNA was extracted using 10 $\mathrm{mM}$ Tris ( $\mathrm{pH} 8.0), 0.5 \mathrm{mM}$ EDTA, and $0.2 \%$ Triton $\mathrm{X}-100$. The lysate was then centrifuged at $4{ }^{\circ} \mathrm{C}$ for 15 minutes at $13,800 \times \mathrm{g}$ to separate the cytoplasmic DNA fragments from the nuclear pellet. The supernatant was then collected and treated with $15 \mu$ l of RNase and incubated at 
Table I: Fold changes in selected genes treated with SB7I5992 tested by microarray analysis.

\begin{tabular}{|c|c|c|c|c|c|}
\hline \multirow[b]{2}{*}{ Accession Number } & \multirow[b]{2}{*}{ Gene Symbol } & \multirow[b]{2}{*}{ Description } & \multicolumn{3}{|c|}{ Fold Change } \\
\hline & & & $6 \mathrm{~h}$ & $24 \mathrm{~h}$ & $48 \mathrm{~h}$ \\
\hline R64I30 & PPBP & pro-platelet basic protein (chemokine (C-X-C motif) ligand 7 ) & 1.07 & 1.74 & 6.50 \\
\hline Al050866 & NODAL & nodal homolog (mouse) & 1.41 & 5.28 & 9.19 \\
\hline NM_00II06 & ACVR2B & activin A receptor, type IIB & 5.66 & 6.50 & | I.3 | \\
\hline NM_005II8 & TNFSFI5 & tumor necrosis factor (ligand) superfamily, member 15 & 1.23 & 4.92 & | I.3 | \\
\hline NM_005228 & EGFR & epidermal growth factor receptor & -1.52 & -1.15 & -2.00 \\
\hline BC00197I & CDKNIB & cyclin-dependent kinase inhibitor IB (p27, Kipl) & 1.32 & 1.23 & 3.03 \\
\hline BC000I25 & TGFBI & transforming growth factor, beta I (Camurati-Engelmann disease) & $-1.4 \mid$ & -1.23 & -2.00 \\
\hline AA994334 & BCLIO & B-cell CLL/lymphoma 10 & 1.74 & 2.46 & 12.13 \\
\hline AV654063 & KRAS2 & v-Ki-ras2 Kirsten rat sarcoma 2 viral oncogene homolog & 18.38 & 13.00 & 19.70 \\
\hline NM_004464 & FGF5 & fibroblast growth factor 5 & -1.32 & -7.46 & -6.06 \\
\hline AK02707I & TSC22 & transforming growth factor beta I induced transcript 4 & NC & 2.83 & 5.28 \\
\hline BG326045 & BHLHB2 & basic helix-loop-helix domain containing, class B, 2 & -1.15 & 2.64 & 9.19 \\
\hline U73844 & ELF3 & E74-like factor 3 (ets domain transcription factor, epithelial-specific) & -1.07 & 2.64 & 6.96 \\
\hline S75264 & WTI & Wilms tumor I & -1.15 & -1.41 & -4.59 \\
\hline AW5 14564 & $\mathrm{CHD} 2$ & chromodomain helicase DNA binding protein 2 & -1.07 & 3.48 & 14.93 \\
\hline AFI 80474 & CNOT3 & CCR4-NOT transcription complex, subunit 3 & -1.52 & -2.14 & -4.29 \\
\hline N95363 & CDKNIC & cyclin-dependent kinase inhibitor IC (p57, Kip2) & -2.00 & 1.23 & 6.06 \\
\hline AL039795 & TARDBP & TAR DNA binding protein & 1.52 & 4.29 & 10.56 \\
\hline AK0225I3 & DUSPIO & dual specificity phosphatase 10 & -1.32 & 3.73 & 8.57 \\
\hline AA994004 & CDKII & cyclin-dependent kinase (CDC2-like) II & 8.57 & 8.00 & 128.00 \\
\hline L78790 & ITGB2 & integrin, beta 2 (antigen CDI8 (p95) & -1.23 & -1.32 & -10.56 \\
\hline NM_003954 & MAP3K 4 & mitogen-activated protein kinase kinase kinase 14 & -1.15 & -1.41 & -2.64 \\
\hline NM_030662 & MAP2K2 & mitogen-activated protein kinase kinase 2 & -1.32 & -1.32 & -2.00 \\
\hline AW025150 & MAP3K 12 & mitogen-activated protein kinase kinase kinase 12 & 1.32 & -1.15 & -2.00 \\
\hline AW450910 & SYK & spleen tyrosine kinase & -1.52 & -1.52 & -14.93 \\
\hline M57765 & ILII & interleukin II & 1.07 & -2.00 & -4.59 \\
\hline AW44476I & CDKN2B & cyclin-dependent kinase inhibitor 2B ( $\mathrm{P} \mid 5$, inhibits CDK4) & 1.07 & 6.06 & 9.19 \\
\hline NM_00203I & FRK & fyn-related kinase & 4.29 & 6.96 & 25.99 \\
\hline
\end{tabular}

$37^{\circ} \mathrm{C}$ for 1 hour. Following incubation, the supernatant was treated with $20 \mu \mathrm{l}$ of $20 \%$ SDS, $8 \mu \mathrm{l}$ of proteinase $\mathrm{K}$ (20 mg/ml), $25 \mu \mathrm{l}$ of $5.0 \mathrm{M} \mathrm{NaCl}$ and allowed to incubate at $37^{\circ} \mathrm{C}$ for 30 minutes. Thereafter, phenol/chloroform/ isoamyl-alcohol extraction and isopropyl alcohol precipitation were carried out. After precipitation, the DNA fragments were washed in $70 \%$ alcohol and separated through a $1.5 \%$ agarose gel at 100 volts for 80 minutes. After electrophoresis, running gels were stained with ethidium bromide and visualized by ultra-violet light.

\section{Microarray analysis for gene expression profiles}

PC-3 cells were treated with 10 nM of SB715992 for 6, 24, and 48 hours respectively. Total RNA was extracted from each sample by the use of Trizol (Invitrogen, Carlsbad, CA) following manufacture's protocol. The total RNA of each sample was then purified with RNeasy Mini Kit and RNase-free DNase Set (Qiagen, Valenica, CA) following manufacturer's protocol. The purified RNA samples were subject to microarray anaylsis using Human Genome U133A Array (Affymetrix, Santa Clara, CA), which contains 54,613 human gene probes. Gene expression was then quantified by using Microarray Suite, MicroDB ${ }^{\mathrm{rm}}$, and
Data Mining Tool Software (Affymetrix, Santa Clara, CA). Clustering and annotation of the gene expression were analyzed by using Cluster and TreeView [8], Onto-Express [9], and GenMAPP [10].

\section{Analysis of RNA expression by reverse transcription- polymerase chain reaction}

To verify the alterations of gene expression at the mRNA level, which appeared on the microarray, we chose representative genes (Table 1 and Table 2 ) with varying expression profiles for real-time RT-PCR analysis. PC-3 cells were treated with $10 \mathrm{nM}$ of SB715992 for 6 and 48 hours and total RNA was isolated and purified as mentioned above. Two micrograms of total RNA from each sample were subjected to reverse transcription using the Superscript first strand cDNA synthesis kit (Invitrogen, Carlsbad, CA) according to the manufacturer's protocol. Real-time PCR reactions were then carried out in a total of $25 \mu \mathrm{L}$ reaction mixture ( $2 \mu \mathrm{l}$ of cDNA, $12.5 \mu \mathrm{l}$ of $2 \times$ SYBR Green PCR Master Mix, $1.5 \mu$ of each $5 \mu \mathrm{M}$ forward and reverse primers, and $7.5 \mu \mathrm{l}$ of $\mathrm{H}_{2} \mathrm{O}$ ) in SmartCycler II (Cepheid, Sunnyvale, CA). The PCR program was initiated by $10 \mathrm{~min}$ at $95^{\circ} \mathrm{C}$ before 40 thermal cycles, each of 


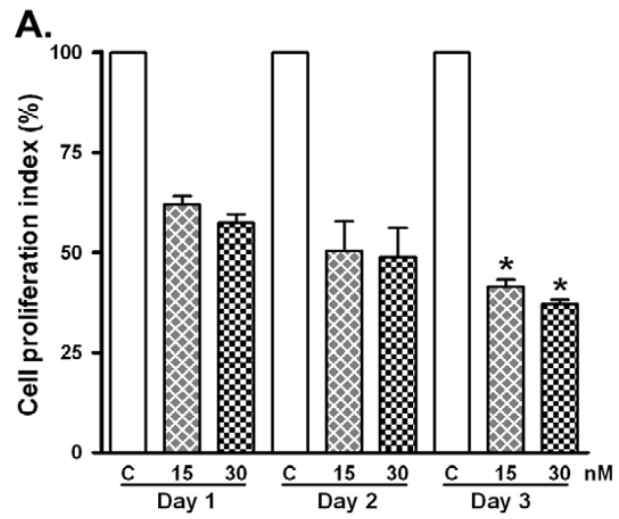

B.
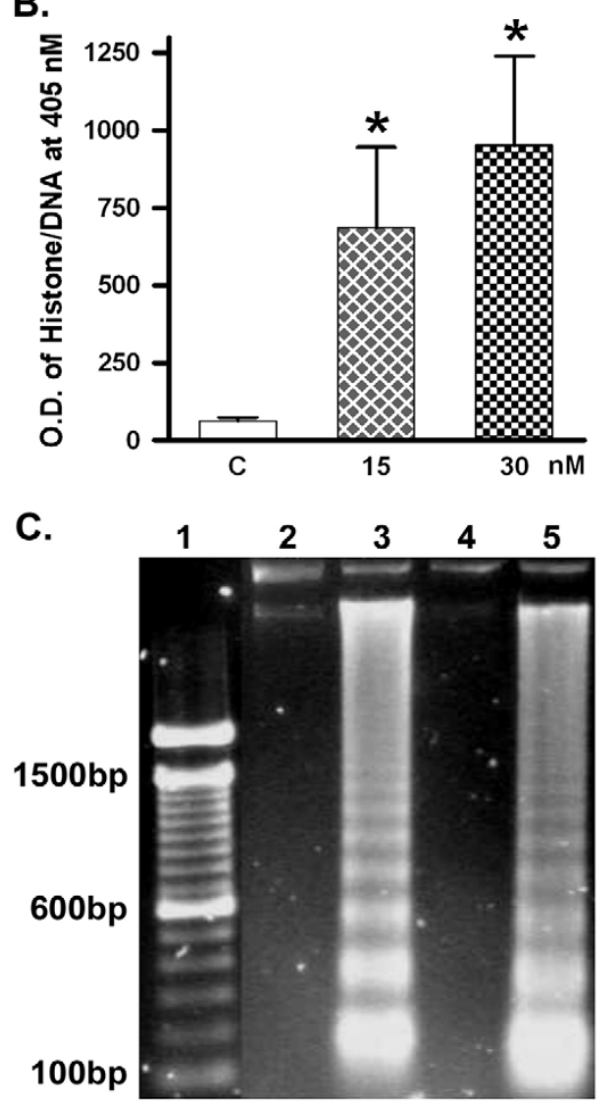

\section{Figure I}

A. Inhibition of PC-3 cell proliferation analyzed by MTT assay. PC- 3 cells were treated with 15 and $30 \mathrm{nM}$ of SB7 I 5992 respectively $(*: P<0.00$ I compared with control, $\mathrm{n}$ $=12$ ). B. Induction of apoptosis in PC-3 cells by SB7I5992 assayed by ELISA. PC-3 cells were treated with 15 and $30 \mathrm{nM}$ of SB7 5992 for 24 to 72 hours $(*: P<0.05, \mathrm{n}=3)$. C. Induction of apoptosis in PC-3 cells by SB7 I5992, measured by DNA-ladder analysis. PC-3 cells were treated with $15 \mathrm{nM}$ of SB715992. (Lanes I: 100 bp DNA marker, 2: Control 48 hours, 3: Treatment 48 hours, 4: Control 72 hours, 5: Treatment 72 hours).
$15 \mathrm{~s}$ at $95^{\circ} \mathrm{C}$ and $1 \mathrm{~min}$ at $60^{\circ} \mathrm{C}$. Data were analyzed according to the comparative $\mathrm{Ct}$ method and were normalized by actin expression in each sample. Melting curves for each PCR reaction were generated to ensure the purity of the amplification product.

\section{Western blot analysis}

PC-3 cells were seeded into $100 \mathrm{~mm}$ culture dishes at 3.0 $\times 10^{5}$ cells per dish and allowed to attach overnight for 24 hours. The cells were treated with $10 \mathrm{nM}$ of SB715992 for 24 and 48 hours. The cells were then lysed in $62.5 \mathrm{mM}$ Tris- $\mathrm{HCl}$ and $2 \%$ SDS. The protein concentrations of each sample were measured using a BCA Protein Assay Kit (PIERCE, Rockford IL). The cellular protein extracts were then subjected to 10 or $14 \%$ of SDS-PAGE and transferred to nitrocellulose membranes at $100 \mathrm{~V}$ for 2 hours at $4{ }^{\circ} \mathrm{C}$. The membranes were incubated with anti-EGFR (1:500, Santa Cruz, CA), anti-p27 (1:100, Santa Cruz, CA), and anti-p15 (1:200, Santa Cruz, CA), and anti- $\beta$-actin (1:10000, Sigma, MO) primary antibodies, and subsequently incubated with secondary antibodies conjugated with peroxidase. The signal was then detected using Chemiluminescent Detection System (PIERCE, Rockford, IL).

\section{Statistical analysis}

For cell growth inhibition assay and apoptosis ELISA, statistical analysis was performed using $t$ test between treated and untreated samples or between monotreatment and combination treatment. $P$ values less than 0.05 indicate statistical significance.

\section{Results \\ Inhibition of PC-3 prostate cancer cell proliferation by SB7। 5992}

PC-3 prostate cancer cells were treated with 15 and $30 \mathrm{nM}$ of SB715992 and assayed for inhibition of cell proliferation. Results obtained from MTT analysis showed that SB715992 had a time and dose related effect on the growth of PC-3 cells (Figure 1a). Over the course of 72 hours, SB715992 caused an average increase in cell growth inhibition of $48.65 \%$ at $15 \mathrm{nM}$ and $52.16 \%$ at 30 $\mathrm{nM}$ with respect to control samples. Therefore, the results from this experiment suggested that SB715992 is a potent inhibitor of PC-3 cell growth in vitro. Given this information, we directed our investigation on the ability of SB715992 to induce apoptosis in PC-3 prostate cancer cells.

Induction of apoptosis in prostate cancer cell by SB7 I 5992 The induction of apoptosis was tested by two different methods. First, the induction of apoptosis by SB715992 was detected by ELISA assay. The results obtained from the ELISA assay showed an average of $1094.88 \%$ increase in apoptosis when PC-3 cells were treated with $15 \mathrm{nM}$ of 
Table 2: List of primer sequences used for RT-PCR analysis.

\begin{tabular}{llll}
\hline Genes & Forward Primer Sequence & Reverse Primer Sequence & PCR Product Size \\
\hline ILII & agctgagggacaaattcc & cacacctgggagctgtag & 104 b.p. \\
CDKII & caaacggaaaactggatg & caggtgtccttgaatgct & 148 b.p. \\
FRK & ccagctccatttgatttg & ttatctgtgcctccctca & 202 b.p \\
PI5 & cacaatggagctagaagca & aattccattttcgaagcc & 153 b.p. \\
CHD2 & aagggactccaaggaatg & aggtttgcatttgtatgctt & 192 b.p. \\
CNOT3 & tggaacgagagaccaaaa & aatccggtcctgcttatc & 218 b.p. \\
P57 & gaccgttcatgtagcagc & caccttgggaccagtgta & 142 b.p. \\
ELF3 & gagtcggaactgagggtt & tgaggaggcaccagataa & 286 b.p. \\
ACVR2B & tcgaagtagagctgtggc & catgcaggtatgagaggc & 138 b.p. \\
TNFSFI5 & ccacctattttgtgctgg & agatgatccacccacctt & 211 b.p. \\
EGFR & gtgctggatgatagacgc & attgttgctggttgcact & 286 b.p. \\
P27 & tggtgatctcccaagcta & aaaactcccaagcacctc & 189 b.p. \\
KRAS2 & cagggcgaatttgtaatg & gttcagtagggcagctca & 229 b.p. \\
FGF & ttgtccttcctcctcctc & agggttcctatcagtggc & 117 b.p. \\
\hline
\end{tabular}

SB715992 and $1516.70 \%$ when treated with $30 \mathrm{nM}$ of SB715992 for 72 hours (Figure 1b). As a result, SB715992 had also shown a time and dose related effect on the increase of apoptosis, which was correlated with our results obtained from MTT assay. Therefore, we decided to confirm our ELISA data by performing a DNA ladder analysis. The results from the DNA ladder analysis also showed a time related increase in apoptosis induced by SB715992 (Figure 1c). Thus, the results from both the ELISA assay and DNA ladder analysis showed clearly that SB715992 was a strong inducer of apoptosis in prostate cancer cells. As a result, the information obtained from the assays for apoptosis and cell proliferation inhibition prompted us to investigate the changes in gene expression and the regulation caused by treatment of PC-3 prostate cancer cells with SB715992.

\section{Regulation of RNA expression by SB7 I5992}

The gene expression profile of PC-3 cells exposed to SB715992 was accessed by microarray analysis using Human Genome U133A Array. Of the 54,613 genes, a total of 120 at 6 hours, 418 at 24 hours, and 1713 at 48 hour were up-regulated after SB715992 treatment. Our data also showed that 126 genes at 6 hours, 110 at 24 hours, and 1264 at 48 hours were down regulated. After clustering and annotation of the gene expression, we selected 34 genes with the most significant changes with respect to categories such as apoptosis, cell cycle, cell proliferation, cell signaling, and protein kinase. Our results showed an up-regulation of genes that induce apoptosis and inhibit cell cycle progression and cell signalling (Table 1). Our results also showed a down regulation of genes related to cell survival, such as protein kinase, growth factors, transcription, and translation (Table 1). To confirm the data from microarray, we conducted RTPCR analysis on 16 of the 34 genes selected from the microarray analysis. The results from our RT-PCR analysis were in mutual agreement with the results obtained from the microarray analysis (Table 3). The data obtained from both RT-PCR and microarray analysis showed clearly that SB715992 up regulated genes that are responsible for apoptosis and cell cycle arrest, and down regulated genes

Table 3: Comparative gene expression levels from microarray and RT-PCR analysis

\begin{tabular}{llcc}
\hline Gene & \multicolumn{1}{c}{ Description } & Microarray 48 h Fold Change & RT-PCR 48 h Fold Change \\
\hline IL-II & interleukin II & -4.59 & -2.13 \\
CDKII & cyclin-dependent kinase (CDC2-like) II & 128.00 & 4.03 \\
FRK & fyn-related kinase & 25.99 & 1.00 \\
PI5 & cyclin-dependent kinase inhibitor 2B (pI5, inhibits CDK4) & 9.19 & 5.4 I \\
CHD2 & chromodomain helicase DNA binding protein 2 & 14.93 & 15.74 \\
CNOT & CCR4-NOT transcription complex, subunit 3 & -4.29 & -5.0 I \\
P57 & cyclin-dependent kinase inhibitor IC (p57, Kip2) & 6.06 & 35.84 \\
ELF3 & E74-like factor 3 (ets domain transcription factor) & 6.96 & 24.53 \\
ACVR & activin A receptor, type IIB & 11.31 & 2.95 \\
TNFSF & tumor necrosis factor (ligand) superfamily, member I5 & 11.31 & 30.00 \\
EGFR & epidermal growth factor receptor & 2.00 & 6.00 \\
P27 & cyclin-dependent kinase inhibitor IB (p27, KipI) & 3.03 & 10.90 \\
KRAS2 & v-Ki-ras2 Kirsten rat sarcoma 2 viral oncogene homolog & 19.7 & 3.56 \\
FGF & fibroblast growth factor & -6.06 & -5.26
\end{tabular}




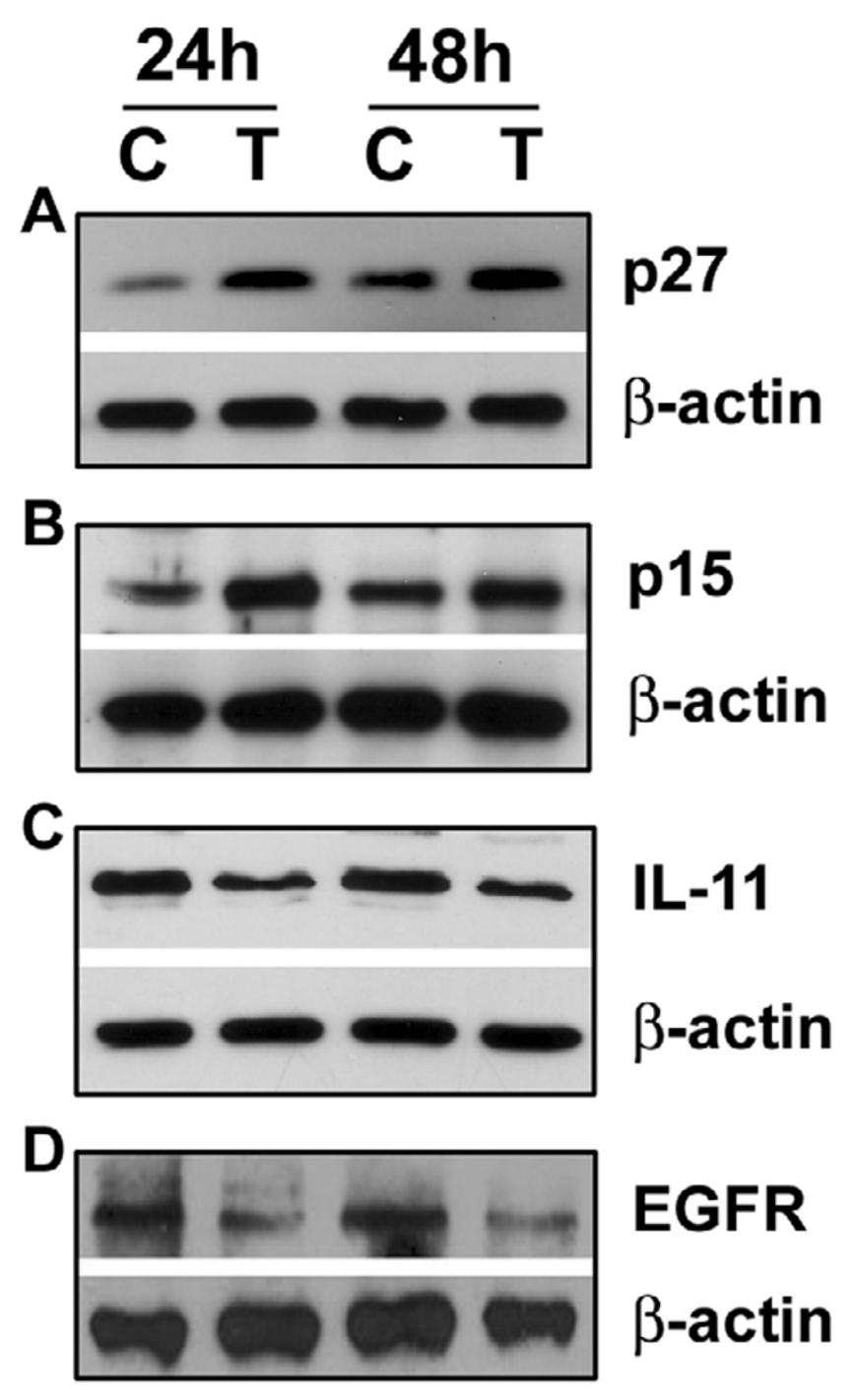

Figure 2

Alteration in protein expression in PC-3 cells treated with SB7I5992 and analyzed by Western Blot analysis. PC-3 cells were treated with $10 \mathrm{nM}$ of SB7I5992 (A. p27/ $\beta$-actin; B. pl5/ $\beta$-actin; C. IL-I I/ $\beta$-actin; D. EGFR/ $\beta$-actin;).

that are responsible for cell proliferation and survival. As a result, alterations in RNA expression of PC-3 cell by SB715992 led us to investigate the alteration in protein expression of selected critical genes, which are expressed in prostate cancer cells and are important for cell cycle regulation and cell growth.

\section{Regulation of protein expression in prostate cancer cells by SB7 I 5992}

In order to investigate the alteration in protein expression in PC-3 cells, Western Blot analysis was conducted. Our results showed a qualitative decrease in the expression of
EGFR after 48 hours of SB715992 (Figure 2a), suggesting a down regulation of EGFR gene. Our results also showed a qualitative increase in the expression of p27 (CDKN2B) and p15 (CDKN1B) (Figure 2b and 2c), suggesting an upregulation of these genes. These results were in direct agreement with the results obtained from microarray analysis and RT-PCR analysis. Therefore, our results obtained by different assays clearly suggest that SB715992 regulates the expression of genes that are vital for cell proliferation and apoptosis. Because we previously found that genistein also regulated the expression of genes that are critical for the control of cell growth and apoptosis, we investigated whether combination treatment with genistein and SB715992 could exert more inhibitory effects on PC-3 prostate cancer cell growth and induce greater degree of apoptotic cell death compared to either agent alone.

\section{Genistein increased anti-proliferation activity of SB7 I 5992}

To investigate whether genistein could potentiate the growth inhibitory effects of SB715992, PC-3 cells were treated with a combination of SB715992 and genistein, and assayed for inhibition of cell proliferation by MTT analysis (Figure 3a). Our results showed an average increase in growth inhibition of $29.83 \%$ when treated with $7.5 \mathrm{nM}$ of SB715992, and 36.99\% when treated with $10 \mathrm{nM}$ of SB715992 over 72 hours. However, when the cells were treated with $7.5 \mathrm{nM}$ SB715992 plus $30 \mu \mathrm{M}$ of genistein, we found $48.73 \%$ growth inhibition over 72 hours. Thus, combining SB715992 with genistein increased the percentage of cell growth inhibition compared to mono-treatments. These results led us to investigate whether pre-treatment with genistein could sensitize PC-3 cells to the growth inhibitory effects of SB715992. We pre-treated PC-3 cells with $30 \mu \mathrm{M}$ of genistein for 24 hours. After the pre-treatment, we exposed the cells to 15 nM of SB715992 for 24 and 72 hours. Our results showed a greater degree of cell growth inhibition compared to cells treated simultaneously with these agents (Figure 3a). We subsequently tested whether genistein could increase the apoptotic inducing effect of SB715992.

\section{Genistein enhanced pro-apoptotic effect of SB7 I5992}

To test for induction of apoptosis, PC-3 cells were treated with $30 \mu \mathrm{M}$ of genistein, $7.5 \mathrm{nM}$ of SB715992 with $30 \mu \mathrm{M}$ of genistein, and $10 \mathrm{nM}$ of SB715992 with $30 \mu \mathrm{M}$ of genistein. PC-3 cells were also treated with 10, 15, and $30 \mathrm{nM}$ of SB715992 for direct comparison (Figure 3b). Our results showed that an average increase in apoptosis was $38.59 \%$ when treated with genistein compared to untreated cells over the course of 72 hours. Also, we observed a $7.44 \%$ increase in apoptosis when treated with $10 \mathrm{nM}$ of SB715992 combined with $30 \mu \mathrm{M}$ genistein with respect to cells only treated with SB715992. These ELISA results were correlated with those obtained by MTT analysis, suggesting that genistein not only induces cell growth 
A.

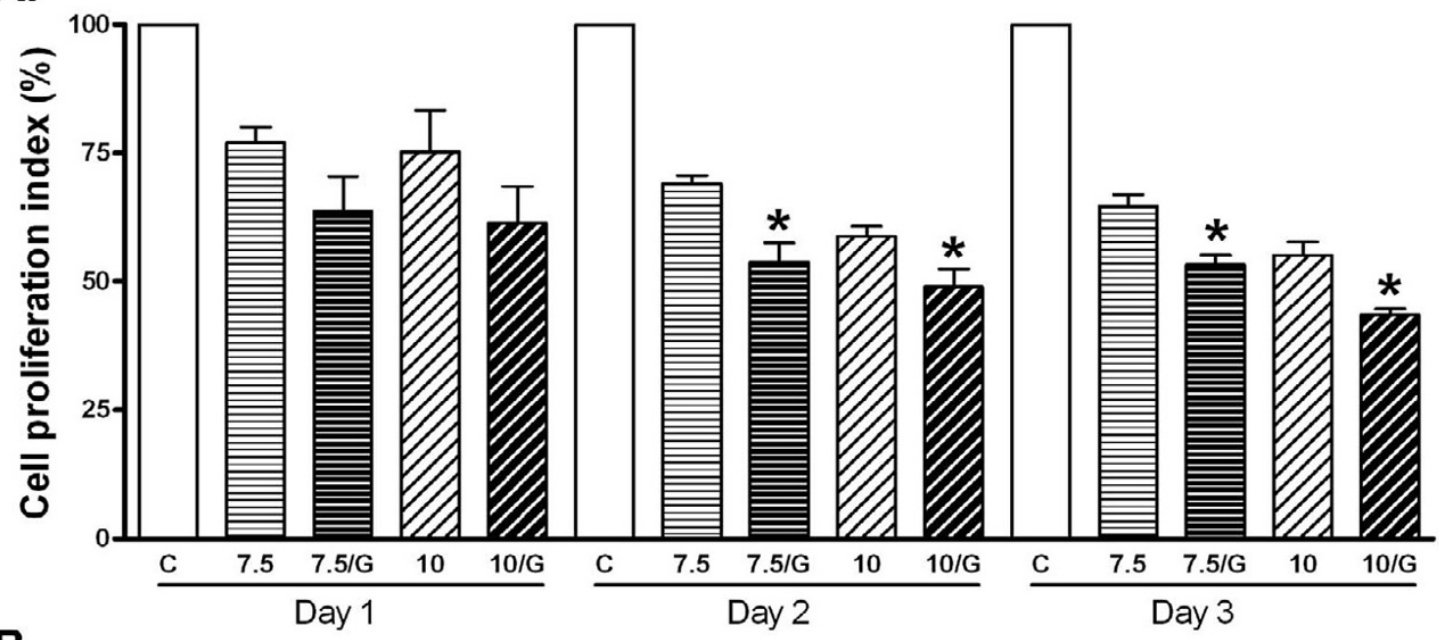

B.
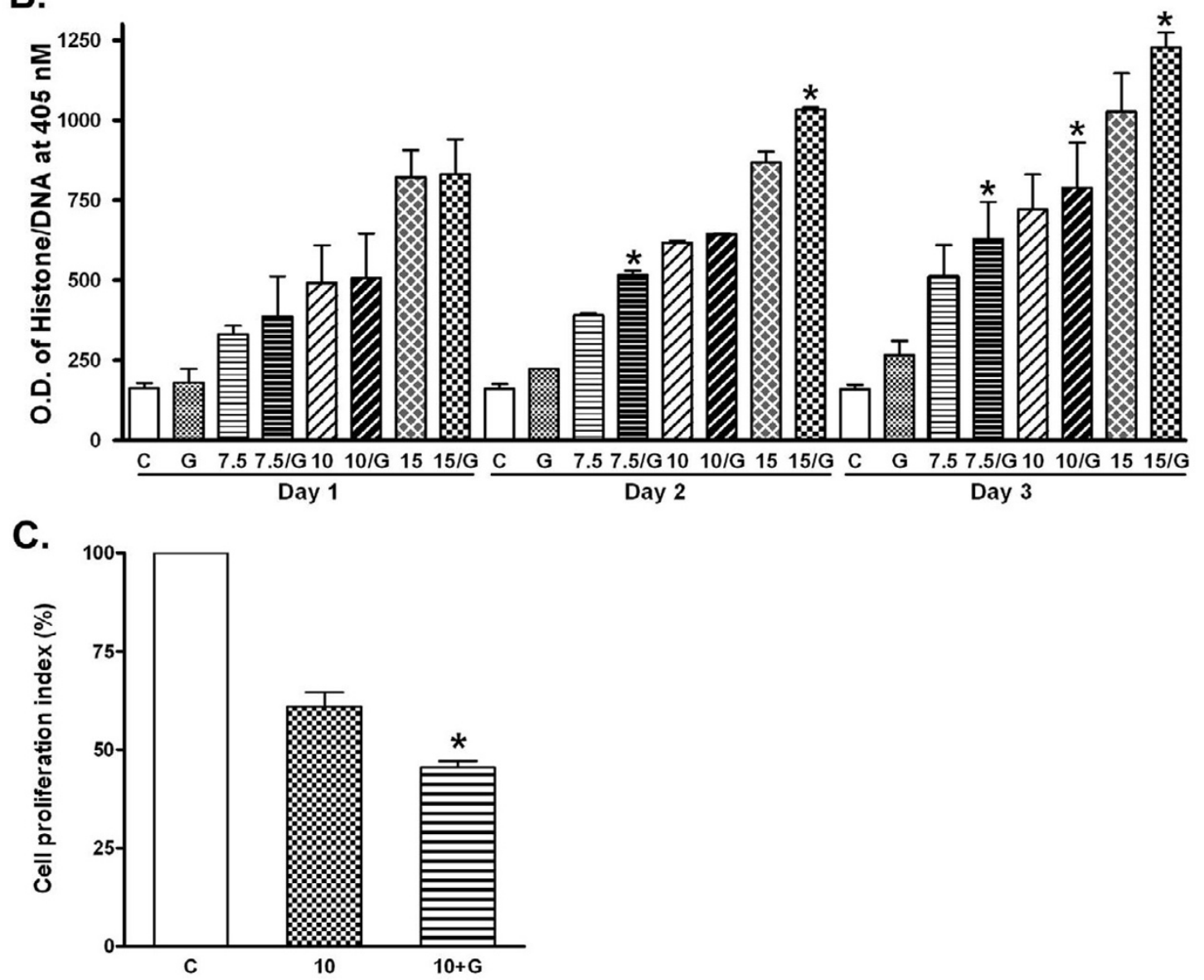

Figure 3

A. Inhibition of PC-3 cell proliferation was enhanced by genistein as measured by MTT assay. G indicates treatment with 30 $\mu \mathrm{M}$ of genistein (*: $P<0.05$ compared with SB7I5992 treatment alone, $\mathrm{n}=5$ ). B. Induction of apoptosis in PC-3 cells was enhanced by genistein. $\mathrm{G}$ indicates treatment with $30 \mu \mathrm{M}$ of genistein. (*: $P<0.05$ compared with SB7 I5992 treatment alone, $\mathrm{n}$ = 3.). C. Inhibition of PC-3 cell proliferation was enhanced by pre-treatment with genistein. $G$ indicates pre-treatment with 30 $\mu \mathrm{M}$ of genistein. (*: $P<0.05$ compared with SB7I5992 treatment alone. $\mathrm{n}=8$ ). 
inhibitory activity of SB715992, but also caused induction of apoptotic cell death.

\section{Discussion}

Cancer chemotherapeutic agents, which target spindle and perturb mitosis, have been shown to be clinically effective for the treatment of cancers. These agents are clinically used mainly for deregulating one motor protein, tubulin. However, kinesin spindle protein (KSP) is another important motor protein, which makes up a larger family of microtubules and forms bipolar spindle with other motor proteins. This motor protein plays an essential role in nuclear motility and mitotic spindle functions $[7,11]$. The mitotic spindle, commonly referred to as the nuclear spindle, is composed of spindle fibers of which some are adhered to chromosomes positioned at centromeres. This effect is apparently involved in chromosomal movement $[12,13]$. The mitotic spindle is also composed of continuous fibers that stretch and pass from pole to pole forming a bipolar spindle. These bipolar spindles are required for proper cell division $[14,15]$. Thus, it is critical that assembly of the spindles is accurate and that they are maintained with high fidelity. Recently, researchers have used this information to produce chemical agents to enhance cessation of the cell cycle and induce apoptosis in mitotic cells, with their principle target being the Homo sapiens Eg5 kinesin spindle protein ( $H s E g 5 / K S P)$ [16]. If the functions of $H s E g 5 / K S P$ can be reversed or inhibited, this could prove to be a novel way to manipulate the cell cycle and cell proliferation in mitotic cells [7]. In this study, we found that SB715992, an experimental KSP inhibitor, significantly inhibited the proliferation of PC-3 human prostate cancer cells at nanomole concentration, suggesting that this inhibitor of KSP may be a potent agent for the treatment of prostate cancer.

Current literature has shown that inhibition of KSP perturbs mitosis and leads to cell death $[7,16-20]$. The inhibition of KSP influences the formation of bipolar spindle that is required for proper separation and lining of the chromosomes during mitosis. This abnormality in chromosomes leads to programmed cell death in mitotic cells [21]. Here, we showed that SB715992 significantly induced apoptotic cell death in PC-3 prostate cancer cells, suggesting that SB715992 could inhibit the formation of bipolar spindle during cell mitosis, resulting in apoptotic cell death of PC-3 cells.

From gene expression profiles altered by SB715992, we found that cellular and molecular responses to SB715992 treatment are complex and are likely to be mediated by a variety of regulatory pathways. SB715992 regulated the expression of important genes that control cell growth, apoptosis, transcription, translation, and cell signaling. These regulations may be responsible for inhibiting the progression of prostate cancers. It has been well known that cyclins associate with cyclin-dependent protein kinases (CDKs) and CDK inhibitors to control the process of cell cycle. The CDK inhibitors such as p $27^{\mathrm{KIP} 1}$, p15, and p57 Kip2 have been demonstrated to arrest the cell cycle and inhibit the growth of cancer cells. From gene expression profiles, we found that SB715992 increased the expression of several cyclin-dependent kinase inhibitors including $\mathrm{p} 27^{\mathrm{KIP} 1}, \mathrm{p} 15$, and $\mathrm{p} 57^{\mathrm{Kip} 2}$, suggesting a positive change in promotion of cyclin-dependent kinase inhibitors, which could ultimately lead to cell cycle arrest (Fig. 4) $[23,24]$. On the other hand, SB715992 decreased the expression of genes such as fibroblast growth factor (FGF) and epidermal growth factor (EGFR) and these genes are important molecules in favour of cell survival and proliferation. Therefore decrease in the expression of these genes could negatively regulate cell cycle progression (Fig. 4), cell proliferation, angiogenesis, motility, metastasis, and cell signaling [22].

Another objective in this study was to investigate whether genistein, a naturally occurring isoflavone, could potentiate the effects of SB715992 on human prostate cancer cells. Previously, genistein has been shown to inhibit nuclear transcription factor, NF- $\kappa \mathrm{B}$ and Akt signaling pathways in cancer cells, leading to apoptosis [21,25-29]. Genistein has also been shown to inhibit angiogenesis and topoisomerase I \& II. Our study showed that genistein increased the growth inhibitory effects of SB715592 on PC-3 cells. In addition, we also found that genistein could also enhance the induction of apoptosis in PC-3 cells induced by SB715992, suggesting that genistein could be clinically useful when combined with SB715992. Therefore, we believe that SB715992 could be used as a novel therapeutic agent for prostate cancer and that the pretreatment of patients with genistein prior to administration of SB715992 could even be a better therapeutic strategy with lowering systemic toxicity caused by SB715992. However, further in-depth investigations including in vivo study are needed in order to establish cause and effect relationships between these altered genes and treatment outcome in animal models as well as in human patients.

\section{Competing interests}

The author(s) declare that they have no competing interests.

\section{Authors' contributions}

FHS designed the study and prepared the manuscript. DAD carried out cell growth inhibition, apoptosis assays, microarray and Western Blot analysis and drafted the manuscript. SHS carried out real-time PCR. MH participated in the design of the study. YL carried out Western Blot analysis and modified the manuscript. All authors read and approved the manuscript. 


\section{Acknowledgements}

This work was partly funded by grants from the National Cancer Institute, $\mathrm{NIH}$ (5ROICAIOI870 and 5ROICA083695) to FHS.

\section{References}

I. Jemal A, Murray T, Ward E, Samuels A, Tiwari RC, Ghafoor A, Feuer EJ, Thun MJ: Cancer statistics, 2005. CA Cancer J Clin 2005, 55: $10-30$.

2. Li Y, Sarkar FH: Inhibition of nuclear factor kappaB activation in PC3 cells by genistein is mediated via Akt signaling pathway. Clin Cancer Res 2002, 8:2369-2377.

3. Barnes S: Effect of genistein on in vitro and in vivo models of cancer. J Nutr 1995, I 25:777S-783S.

4. Kumar NB, Cantor A, Allen K, Riccardi D, Besterman-Dahan K, Seigne J, Helal M, Salup R, Pow-Sang J: The specific role of isoflavones in reducing prostate cancer risk. Prostate 2004, 59:|4|-| 47.

5. Li Y, Sarkar FH: Gene expression profiles of genistein-treated PC3 prostate cancer cells. I Nutr 2002, I 32:3623-363 I.

6. Robinson DR, Wu YM, Lin SF: The protein tyrosine kinase family of the human genome. Oncogene 2000, 19:5548-5557.

7. Sakowicz R, Finer JT, Beraud C, Crompton A, Lewis E, Fritsch A, Lee Y, Mak J, Moody R, Turincio R, Chabala JC, Gonzales P, Roth S, Weitman S, Wood KW: Antitumor activity of a kinesin inhibitor. Cancer Res 2004, 64:3276-3280.

8. Eisen MB, Spellman PT, Brown PO, Botstein D: Cluster analysis and display of genome-wide expression patterns. Proc Natl Acad Sci U S A 1998, 95:|4863-|4868.

9. Khatri P, Draghici S, Ostermeier GC, Krawetz SA: Profiling gene expression using onto-express. Genomics 2002, 79:266-270.

10. Dahlquist KD, Salomonis N, Vranizan K, Lawlor SC, Conklin BR: GenMAPP, a new tool for viewing and analyzing microarray data on biological pathways. Nat Genet 2002, 31:19-20.

I I. Kim AJ, Endow SA: A kinesin family tree. J Cell Sci 2000, I I3 Pt 2I:368I-3682

12. Abal M, Keryer G, Bornens M: Centrioles resist forces applied on centrosomes during G2/M transition. Biol Cell 2005, 97:425-434

13. Cochran JC, Sontag CA, Maliga Z, Kapoor TM, Correia J], Gilbert SP. Mechanistic analysis of the mitotic kinesin Eg5. J Biol Chem 2004, 279:3886I-38870.

14. Kapitein LC, Peterman EJ, Kwok BH, Kim JH, Kapoor TM, Schmidt CF: The bipolar mitotic kinesin Eg5 moves on both microtubules that it crosslinks. Nature 2005, 435: I |4- I I8.

I5. Whitehead CM, Rattner JB: Expanding the role of HsEg5 within the mitotic and post-mitotic phases of the cell cycle. J Cell Sci |998, I I I ( Pt | 7):255I-256I.

16. DeBonis S, Simorre JP, Crevel I, Lebeau L, Skoufias DA, Blangy A, Ebel C, Gans P, Cross R, Hackney DD, Wade RH, Kozielski F: Interaction of the mitotic inhibitor monastrol with human kinesin Eg5. Biochemistry 2003, 42:338-349.

17. Cox CD, Breslin MJ, Mariano BJ, Coleman PJ, Buser CA, Walsh ES, Hamilton K, Huber HE, Kohl NE, Torrent M, Yan Y, Kuo LC, Hartman GD: Kinesin spindle protein (KSP) inhibitors. Part I: The discovery of 3,5-diaryl-4,5-dihydropyrazoles as potent and selective inhibitors of the mitotic kinesin KSP. Bioorg Med Chem Lett 2005, I 5:204I-2045.

18. Gartner M, Sunder-Plassmann N, Seiler J, Utz M, Vernos I, Surrey T, Giannis A: Development and biological evaluation of potent and specific inhibitors of mitotic Kinesin Eg5. Chembiochem 2005, 6:1173-1177.

19. Haque SA, Hasaka TP, Brooks AD, Lobanov PV, Baas PW: Monastrol, a prototype anti-cancer drug that inhibits a mitotic kinesin, induces rapid bursts of axonal outgrowth from cultured postmitotic neurons. Cell Motil Cytoskeleton 2004, 58: 10-16.

20. Marcus AI, Peters U, Thomas SL, Garrett S, Zelnak A, Kapoor TM, Giannakakou P: Mitotic kinesin inhibitors induce mitotic arrest and cell death in Taxol-resistant and -sensitive cancer cells. J Biol Chem 2005, 280: I I569- I I 577.

21. Turner J, Anderson R, Guo J, Beraud C, Fletterick R, Sakowicz R: Crystal structure of the mitotic spindle kinesin Eg5 reveals a novel conformation of the neck-linker. I Biol Chem 200I, 276:25496-25502

22. Gandour-Edwards R, Mack PC, vere-White RW, Gumerlock PH: Abnormalities of apoptotic and cell cycle regulatory proteins in distinct histopathologic components of benign prostatic hyperplasia. Prostate Cancer Prostatic Dis 2004, 7:321-326.
23. Poon RY, Toyoshima H, Hunter T: Redistribution of the CDK inhibitor p27 between different cyclin.CDK complexes in the mouse fibroblast cell cycle and in cells arrested with lovastatin or ultraviolet irradiation. Mol Biol Cell 1995, 6: I I97-I2 I3.

24. Vallbohmer D, Lenz HJ: Epidermal growth factor receptor as a target for chemotherapy. Clin Colorectal Cancer 2005, 5 Suppl I:S19-S27.

25. Gong L, Li Y, Nedeljkovic-Kurepa A, Sarkar FH: Inactivation of NFkappaB by genistein is mediated via Akt signaling pathway in breast cancer cells. Oncogene 2003, 22:4702-4709.

26. Li Y, Ellis KL, Ali S, El-Rayes BF, Nedeljkovic-Kurepa A, Kucuk O, Philip PA, Sarkar FH: Apoptosis-inducing effect of chemotherapeutic agents is potentiated by soy isoflavone genistein, a natural inhibitor of NF-kappaB in BXPC-3 pancreatic cancer cell line. Pancreas 2004, 28:e90-e95.

27. Rao A, Coan A, Welsh JE, Barclay WW, Koumenis C, Cramer SD: Vitamin D receptor and p2 I/WAF I are targets of genistein and I,25-dihydroxyvitamin D3 in human prostate cancer cells. Cancer Res 2004, 64:2143-2147.

28. Sarkar FH, Li Y: Mechanisms of cancer chemoprevention by soy isoflavone genistein. Cancer Metastasis Rev 2002, 2 I:265-280.

29. Sarkar FH, Li Y: Cell signaling pathways altered by natural chemopreventive agents. Mutat Res 2004, 555:53-64.

\section{Pre-publication history}

The pre-publication history for this paper can be accessed here:

http://www.biomedcentral.com/1471-2407/6/22/prepub
Publish with Biomed Central and every scientist can read your work free of charge

"BioMed Central will be the most significant development for disseminating the results of biomedical research in our lifetime. "

Sir Paul Nurse, Cancer Research UK

Your research papers will be:

- available free of charge to the entire biomedical community

- peer reviewed and published immediately upon acceptance

- cited in PubMed and archived on PubMed Central

- yours - you keep the copyright

Submit your manuscript here:

http://www.biomedcentral.com/info/publishing_adv.asp
BiolMedcentral 